\title{
Dimethylsulphide production by plankton communities
}

\author{
Rik L. J. Kwint ${ }^{1,2, *}$, Kees J. M. Kramer ${ }^{2, * *}$ \\ ' University of Groningen, Dept of Microbiology, PO Box 14, 9750 AA Haren, The Netherlands \\ ${ }^{2}$ Laboratory for Applied Marine Research, TNO Institute of Environmental Sciences, PO Box 57, 1780 AB Den Heider, \\ The Netherlands
}

\begin{abstract}
The trends of dimethylsulphide (DMS) production by plankton communities in mesocosm systems were studied under various conditions. The results show that the DMS concentration in the water column can be highly variable over time, even within days, and under apparently identical conditions. DMS release in the water column appears to be highly correlated with phytoplankton senescence rather than growth. The development of the DMS peak could not be attributed to the zooplankton activity. It is argued that bacterial consumption may be an important sink for DMS.
\end{abstract}

KEY WORDS: DMS production Diatoms Phaeocystis Senescence - Mesocosms

\section{INTRODUCTION}

The production of dimethylsulphide (DMS) in the marine environment and its release to the air is one of the most important biogenic sources of sulphur in the atmosphere (Charlson et al. 1987, Bürgermeister \& Georgii 1991, Leck \& Rohde 1991). DMS is derived from the precursor $\beta$-dimethylsulphoniopropionate (DMSP), which is believed to be an osmoregulator in marine algae (Andreae 1990, Kiene \& Service 1991).

A direct correlation between chlorophyll a (chl a) and DMS concentration does not appear to exist in oceanic surface waters (Turner et al. 1988, 1989, Cooper \& Matrai 1989). DMSP is associated with algal classes including dinoflagellates and prymnesiophytes although there is a wide variation in the potential of algae to produce DMSP (Keller et al. 1989, Wakeham \& Dacey 1989). Belviso et al. (1990) found that DMSP was predominantly associated with small dinoflagellates. Gibson et al. (1990) and Kirst et al. (1992) reported

- Address correspondence to the Laboratory for Applied Marine Research

"-Present address: Mermayde, PO Box 109, 1860 AC Bergen, The Netherlands significant correlations between DMS concentration and the biomass of the algae Phaeocystis sp. According to Liss et al. (1992), Emiliania huxleyi is potentially the most important DMSP producer, together with Phaeocystis sp., while diatoms are less important producers. Suggestions for mechanisms controlling the release of DMS into the water column and, subsequently, into the atmosphere are shown in Fig. 1. They include:

(1) Metabolic excretion associated with phytoplankton growth. DMS may be a normal excretion product for algae and its production related to the total phytoplankton biomass (Vairavamurthy et al. 1985, Belviso et al. 1990, Gibson et al. 1990).

(2) Phytoplankton senescence. When algae die and the cells disintegrate, cellular DMSP is released and converted to DMS (Nguyen et al. 1988, Matrai \& Keller 1993, Stefels \& van Boekel 1993).

(3) Zooplankton grazing. This may initiate a release of cellular DMSP into the water column by damaging phytoplankton cells during capture and (sloppy) feeding, or DMSP may be ingested by zooplankton and excreted as DMS and/or DMSP (Dacey \& Wakeham 1986. Wakeham \& Dacey 1989, Leck et al. 1990, Belviso et al. 1990, 1993).

It is not easy to distinguish between these processes in the natural environment. As the time scales of phyto- 


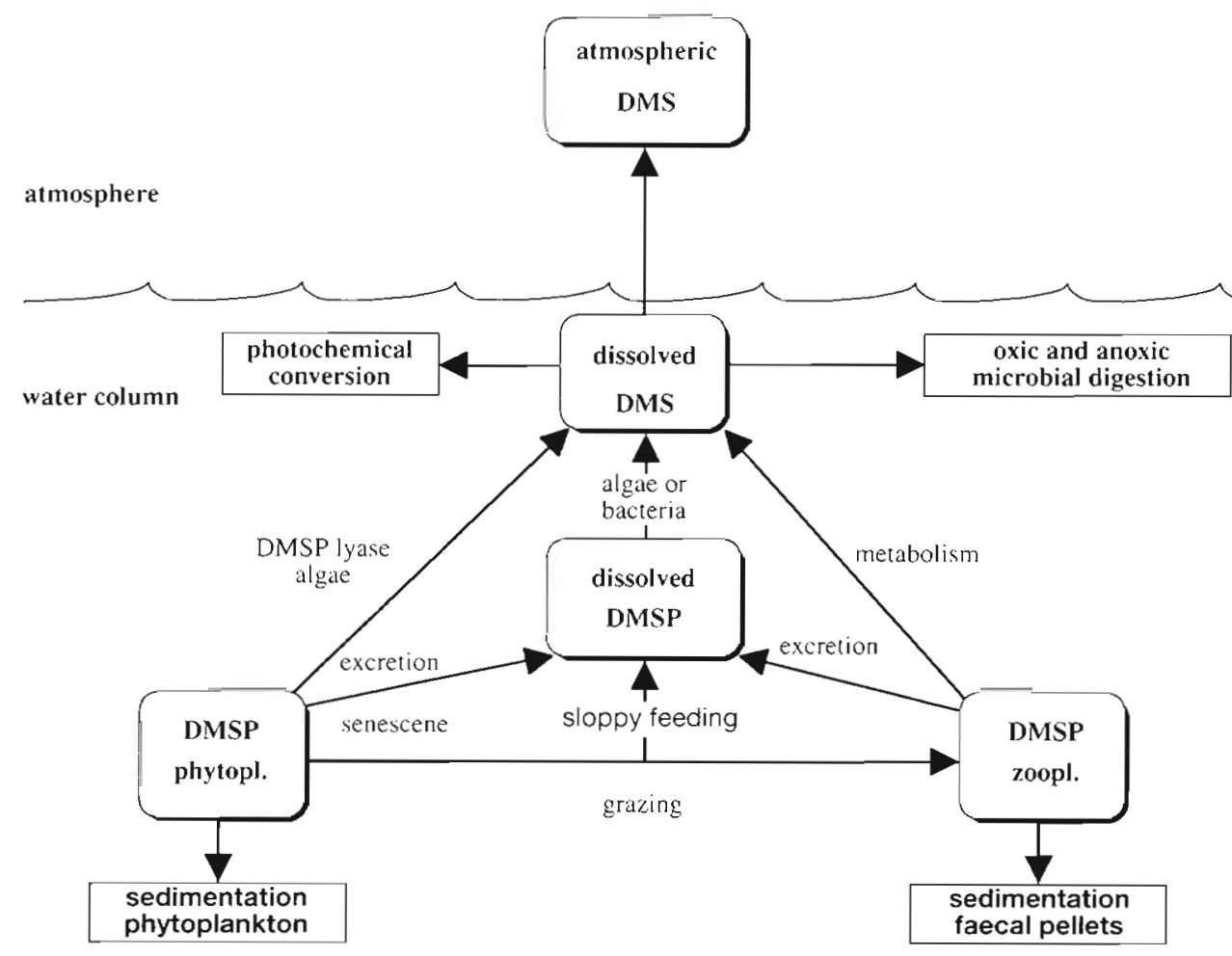

Fig. 1. Schematical representation of mechanisms controlling the release of demethylsulphide (DMS) and $\beta$-dimethylsulphonioproprionate (DMSP) into the water column plankton cycles are of the order of weeks, it is practically impossible to sample from the same water mass and plankton assemblage in a time series and to study interactions between several trophic levels consistently over longer periods. It is also difficult to extrapolate small-scale laboratory experiments to the field situation. Experiments in large-scale experimental systems (mesocosms) may reveal some of the interactions. The advantage of this approach is that the same water mass and plankton (phytoplankton and zooplankton) community can be followed under semifield conditions in these large 'test tubes'. Duplicate systems develop similarly over a time scale of weeks to months, while the size is small enough to allow for experimentation. Repetitive sampling can be performed without major disturbance during the experiment. Previous studies already show that it is possible to relate differences between the individual systems to the different conditions under which the plankton develops. As the plankton community is enclosed, the development of the phytoplankton bloom is compressed in time due to boundary conditions so that, for example, a normal spring diatom/Phaeocystis succession of \pm 2 to 3 mo in the North Sea (Reid et al. 1990) is compressed into \pm 1 mo (Kuiper 1982).

This paper describes the results of 2 separate mesocosm experiments, one carried out in SeptemberOctober 1991 and one in March-April 1992, at the beginning of the spring bloom. Full cycles of the for- mation and decay of the phytoplankton blooms and DMS production were monitored as the function of 2 variables. The effect of the presence or absence of zooplankton was studied in order to estimate the importance of grazing, while variation in the addition of nutrients allowed us to investigate the dependence of DMS production on nutrient availability. In the first experiment the main objective was to investigate whether most of the DMS would be released during growth or during senescence of the phytoplankton bloom and to study the influence of nutrient limitation and zooplankton grazing on this release. In the second experiment, attention was focused on the effect of zooplankton grazing only. Actual fluxes of DMS into the atmosphere were also determined in one of the mesocosms used in this experiment, as reported by Kwint et al. (1992).

\section{MATERIALS AND METHODS}

Each mesocosm system consisted of a plastic bag (polythene/polyamide double-layered foil) with a depth of approximately $3 \mathrm{~m}$ and a diameter of $0.75 \mathrm{~m}$, thus giving a volume of roughly $1.3 \mathrm{~m}^{3}$. The bags were suspended in the water from an aluminium frame and covered with clear Perspex shields. Ambient temperature and light remained close to the natural situation (see Kuiper 1982). In each experiment the 
enclosures were filled simultaneously via a branched pipe, after which they were dosed with different concentrations of nutrients. During filling, the water was filtered through a $2 \mathrm{~mm}$ mesh in order to remove the larger predators.

In Expt I, carried out from 29 August to 4 October 1991, 7 mesocosms were installed in Den Helder harbour, and were filled with water taken from the Oosterschelde basin which is a tidal inlet in the southwest of The Netherlands. The reason for not using local water from the Marsdiep tidal inlet was entirely logistical. Water was collected $4 \mathrm{~d}$ before the experiment started, filling of the systems $3 \mathrm{~d}$ beforehand, while nutrient dosing took place on Day 0 . Different concentrations of phosphate and nitrate were added to all systems (Table 1). Because in autumn there were very low levels of nutrients occurring naturally, the control mesocosms were also dosed to ensure that a phytoplankton bloom would develop. The experiment ended on Day 32. To investigate whether copepod grazing has an influence on DMS release, $0.45 \mu \mathrm{M} \mathrm{CdCl}_{2}$ was added to 2 of the bags on Day 0 in order to inhibit copepod development.

In Expt II, carried out from 23 March to 28 April 1992, seawater was collected in the Marsdiep channel (coastal North Sea) at high tide by means of a floating water tank $2 \mathrm{~d}$ before the experiment started. The tank was left alongside the raft until the next day to allow most of the suspended particulate matter to be deposited. Filling of the mesocosms took place $1 \mathrm{~d}$ before the start of the experiment. During filling, water for mesocosms 1 and 2 was additionally filtered over a $55 \mu \mathrm{m}$ mesh in order to remove copepods. As DMSP may be a substitute for glycine-betaine during nitrogen limitation (Turner et al. 1988, Leck et al. 1990, Gröne \& Kirst 1992), mesocosms 5 and 6 were dosed with $10 \mu \mathrm{M}$ phosphate on Day 0 in order to create a nitrogen-limited phytoplankton bloom. Mesocosms 3 and 4 were controls (no treatment)

Water samples were collected in a 31 glass bottle using a peristaltic pump with Teflon tubing in a depth-

Table 1. Overview of the experimental treatments for the 7 mesocosm systems in Expt I

\begin{tabular}{|cccc|}
\hline Mesocosm & $\begin{array}{c}\mathrm{NO}_{3}^{-} \\
(\mu \mathrm{M})\end{array}$ & $\begin{array}{c}\mathrm{PO}_{4}{ }^{3-} \\
(\mu \mathrm{M})\end{array}$ & $\begin{array}{c}\mathrm{CdCl}_{2} \\
(\mu \mathrm{M})\end{array}$ \\
\hline 1 & 90 & 7 & 0.45 \\
2 & 90 & 7 & 0.45 \\
3 & 20 & 2 & - \\
4 & 20 & 2 & - \\
5 & 90 & 7 & - \\
6 & 90 & 7 & - \\
7 & 20 & 2 & \\
\hline
\end{tabular}

transect through the bags. Subsamples for chl a, phytoplankton, nutrient and DMS determinations were immediately taken from this large sample. The remainder was returned to the mesocosm. Chl a subsamples were stored in $1 \mathrm{l}$ polyethylene bottles in the dark, nutrient subsamples were deep frozen until analysis, while samples for the determination of the phytoplankton species composition were conserved with and stored in Lugol (1\%). DMS subsamples were taken in dark glass-stoppered bottles $(100 \mathrm{ml})$ and stored on ice until further treatment on the day of sampling.

Zooplankton samples were taken twice weekly with a $3 \mathrm{~m}$ PVC pipe, equipped with a ball valve at the end, according to Kuiper (1981), filtered over a $55 \mu \mathrm{m}$ mesh and immediately fixed with neutral buffered formalin or glutaraldehyde. The filtered water (35 1) was returned to the mesocosm.

Chl a samples were filtered on glass-fibre filters (Whatmann GF/C), extracted with $90 \%$ acetone and analyzed on a spectrophotometer within $2 \mathrm{~h}$ of sampling according to standard procedures (Parsons et al. 1984). Nutrient samples were analyzed for orthophosphate, ammonia, nitrate, nitrite and reactive silicate using a Technicon auto-analyzer (Parsons et al. 1984).

Phytoplankton, preserved with Lugol, were counted and identified in a $5 \mathrm{ml}$ inverted microscope chamber. At least 25 fields were counted per sample (magnification 400x). Zooplankton were counted and identified microscopically in a $1 \mathrm{ml}$ chamber and subdivided into adult copepods, copepodites and nauplii.

A preliminary quantification of the DMS oxidizing bacteria population was made in Expt II, using a most probable number (MPN) method (de Man 1975). The triplicate 10 -fold dilution series $\left(10^{-3}\right.$ to $\left.10^{-9}\right)$ in a mineral medium was incubated in an atmosphere of DMS in the dark at $25^{\circ} \mathrm{C}$ for 4 wk. DMS was the only carbon source. Positive tubes were scored on both acidification and increased turbidity.

The DMS water samples were treated immediately after returning to the laboratory. A subsample of 10 to $50 \mathrm{ml}$ was gently poured over a Whatman GF-C filter into a glass tube. No pressure or suction was applied in order to minimize interference by damaged cells. The filtered water was purged with high grade helium at

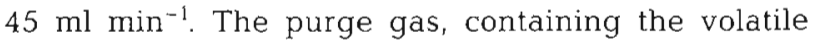
compounds, was dried using a Nafion permeation drier (Dupont, model MD-125 P/F). Nitrogen was used as the drying gas. The dried helium was led through a cold trap, consisting of a straight glass tube containing $200 \mathrm{mg}$ of Tenax-ta 60/80 (Chrompack). This cold trap was placed horizontally over a Dewar flask filled with liquid nitrogen. Cooling was achieved with aluminium strips placed over the cold trap into the nitrogen in 
order to achieve a temperature of $-120^{\circ} \mathrm{C}$. The temperature was checked periodically. After 15 to $25 \mathrm{~min}$ of purging, the collection tube was closed at both ends with Swagelock caps (stainless steel, fitted with Teflon ferrules) and stored in liquid nitrogen until analysis (adapted from Lindquist 1989). Storage tests with calibration gas showed that samples can be stored in this way for at least 8 wk without change.

DMS samples were analyzed according to Lindqvist (1989) on a Varian 3700 gas chromatograph equipped with a capillary linear plot column and a photoionization detector (PID) of $10.2 \mathrm{eV}$ and with hydrogen as the carrier gas. The detection limit for DMS was 1.5 pmol. Calibration was performed using carbonylsulphide (COS), DMS and dimethyldisulphide (DMDS) permeation tubes in a dynamic dilution system. The coefficients of variation (CVs) for the DMS analyses for independent analyses were no larger than 5\% for samples with a concentration over $100 \mathrm{nM}$ to $17 \%$ for samples with a concentration below this value.

\section{RESULTS}

\section{Expt I (September-October 1991)}

Fig. 2 a shows the chl a results for the 7 mesocosms. In all systems the first peak was mainly caused by diatoms, especially Asterionella sp. $\left(7 \times 10^{6} \mathrm{l}^{-1}\right)$, Chaetoceros sp. $\left(2 \times 10^{6} 1^{-1}\right)$ and Nitszchia spp. $\left(5 \times 10^{6}\right.$ $\left.\mathrm{l}^{-1}\right)$ species at the maximum chl a concentrations. Flagellates in the size ranges $<3$ and $3-5 \mu \mathrm{m}$ were also present $\left(6 \times 10^{6} 1^{-1}\right)$.

After Day 5 the diatom bloom collapsed, probably due to the lack of silicate (which was below detection limits during the entire experiment) and after Day 7 a second phytoplankton bloom began, with a second maximum on Day 11 . This chl a maximum was mainly caused by flagellates $3-5 \mu \mathrm{m}$ in diameter and Phaeocystis sp. with a cell number altogether of $11 \times 10^{6} \mathrm{I}^{-1}$ in the controls to $27 \times 10^{6} \mathrm{l}^{-1}$ in the nutrient-dosed systems (at maximum chl a concentration).
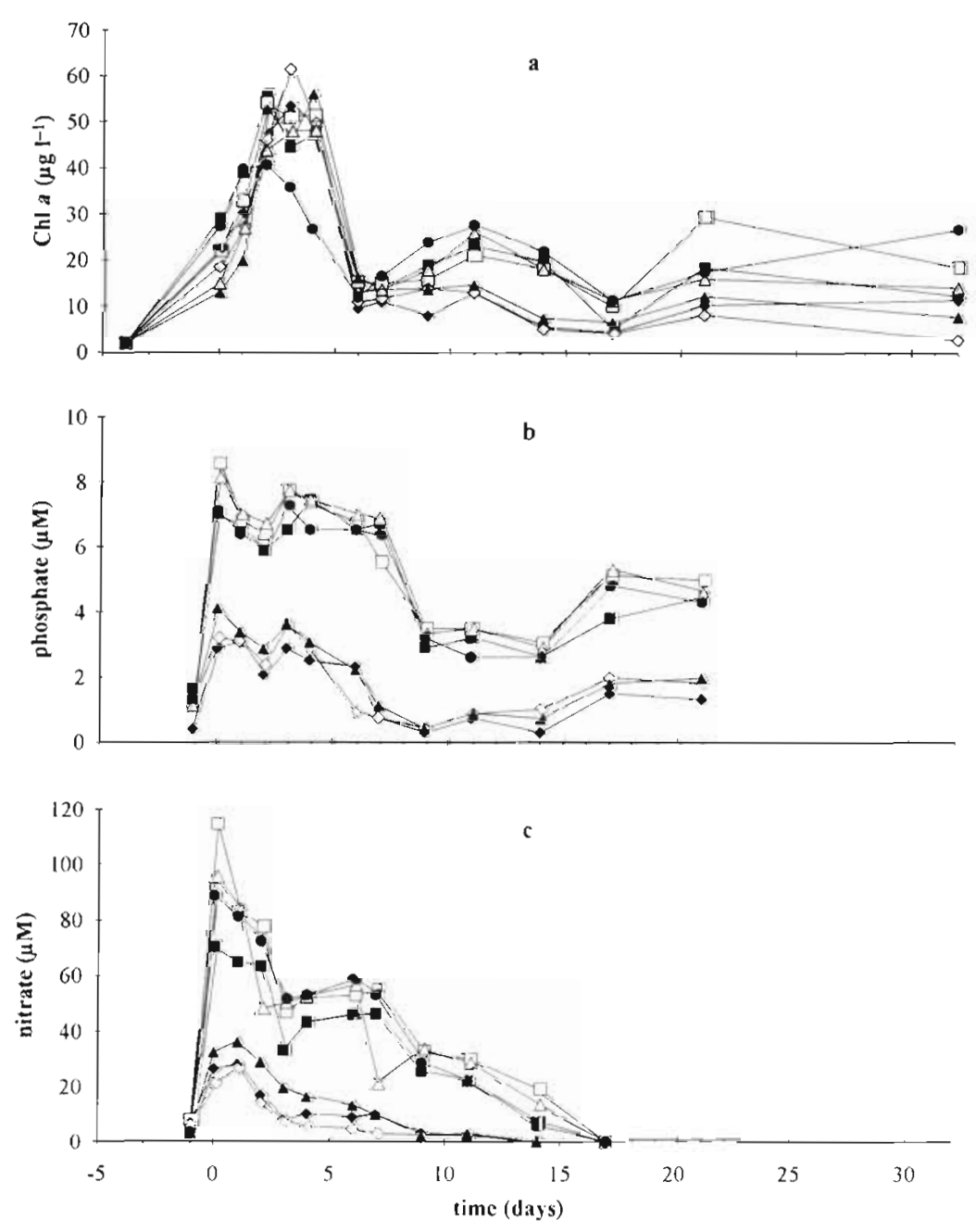

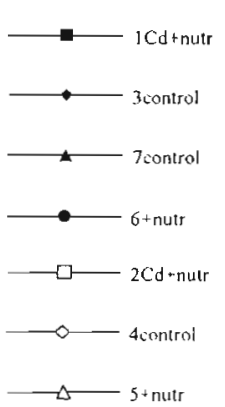

Fig. 2. Change in (a) chlorophyll $a_{1}$ (b) phosphate and (c) nitrate concentrations for the 7 mesocosms in Expt I (Sep-Oct 1991). See Table 1 for an explanation of nutrient and $\mathrm{Cd}$ levels added 
Fig. 3. Development of DMS concentrations in water for the 7 mesocosms in Expt I (1991), plotted together with chl a concentrations. Treatments described in Table 1
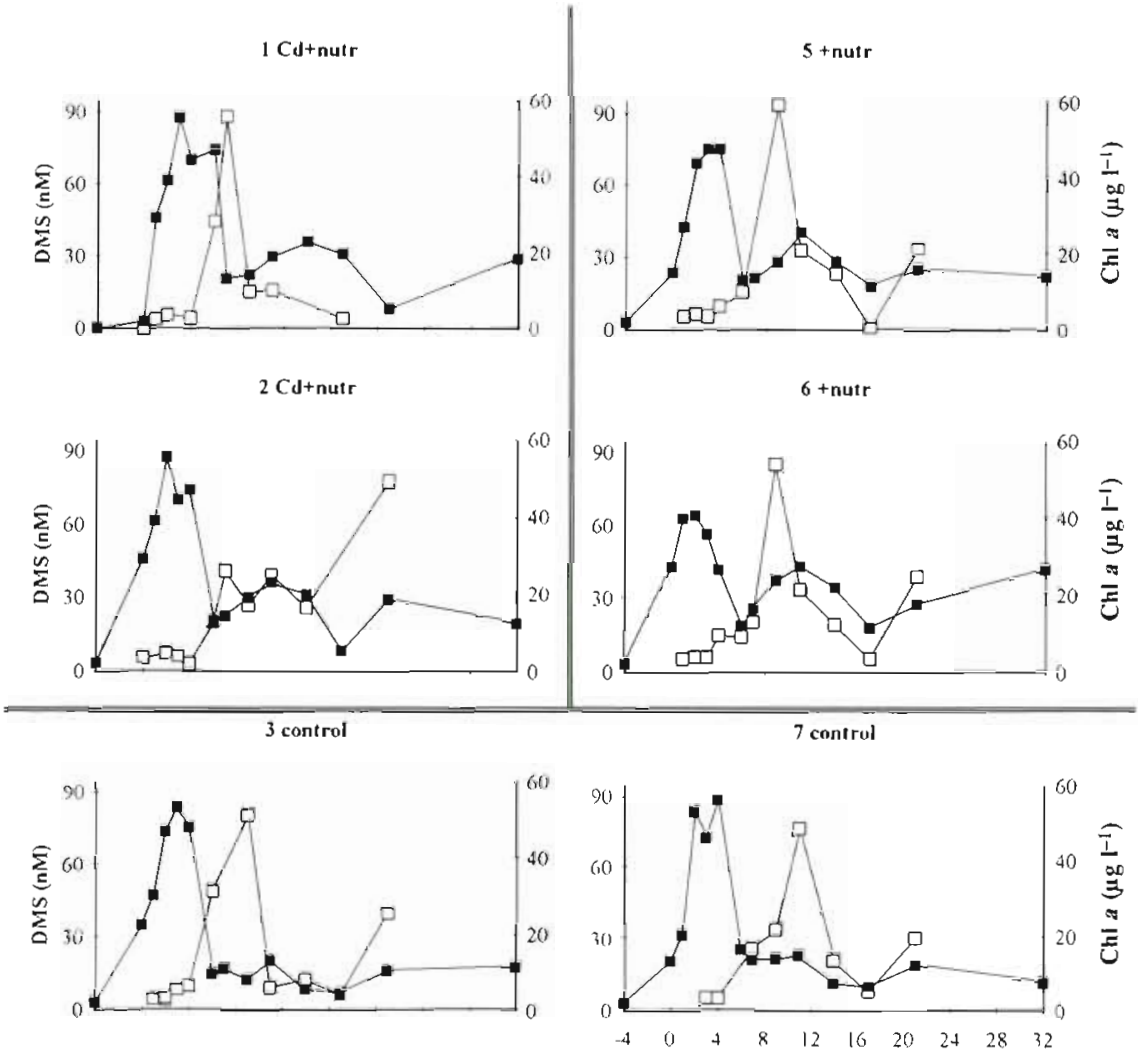

t contrul

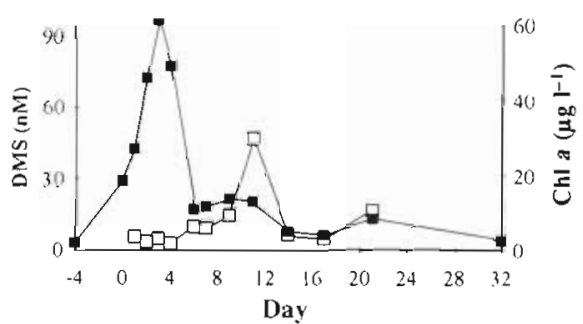

Day

- Clil a $\square$ DMS

The measured concentrations of nutrients in the 7 mesocosms are given in Fig. 2b, $c$; the difference in the nutrient regime between the systems is evident. Nitrate was depleted to below the detection limits in the controls on Day 14, while in the nutrient-dosed systems and the mesocosms with nutrient and $\mathrm{CdCl}_{2}$ addition, nitrate was depleted on Day 17. The stabilization and increase of the phosphate concentration shows that remineralization had already taken place in the bags from Day 9 onwards. Controls and mesocosms with extra $\mathrm{PO}_{4}{ }^{3-}$ added used about the same amount of phosphate. Silicate remained below detection limits during the entire experiment.

In Fig. 3, the results of the DMS measurements are shown together with the chl a concentrations. In all mesocosms the development followed a more or less similar pattern. Initially, the concentration of DMS in water ([DMS $\left.\right|_{\text {water }}$ ) was relatively low, 3 to $6 \mathrm{nM}$ DMS and there was virtually no [DMS $]_{\text {water }}$ increase during the exponential phase of the phytoplankton bloom.
Just after the maximum concentration of the first chl a peak, [DMS] water increased rapidly within $4 \mathrm{~d}$ to a maximum value of about $90 \mathrm{nM}$. In 2 cases, mesocosms 2 and 4, the DMS maximum reached was much less pronounced. Two days after the maximum, [DMS] water had already declined to less than one-third of this peak value. Near the end of the experiment, between Days 16 and 21, the DMS concentrations increased again. The exact maximum of [DMS $]_{\text {water }}$ in the senescent stage of the second bloom (flagellates and Phaeocystis sp.) was not determined as the experiment was terminated before this point was reached. The $\left[\left.D M S\right|_{\text {water }}\right.$ outside the mesocosms was measured at weekly intervals and appeared to be about $15 \mathrm{nM}$. DMDS and COS were present during the entire experiment at low background concentrations (1.5 nM and $0.5 \mathrm{nM}$ respectively).

Zooplankton development is shown in Fig. 4. In the mesocosms with the highest initial nutrient concentrations and no cadmium addition, the zooplankton abun- 

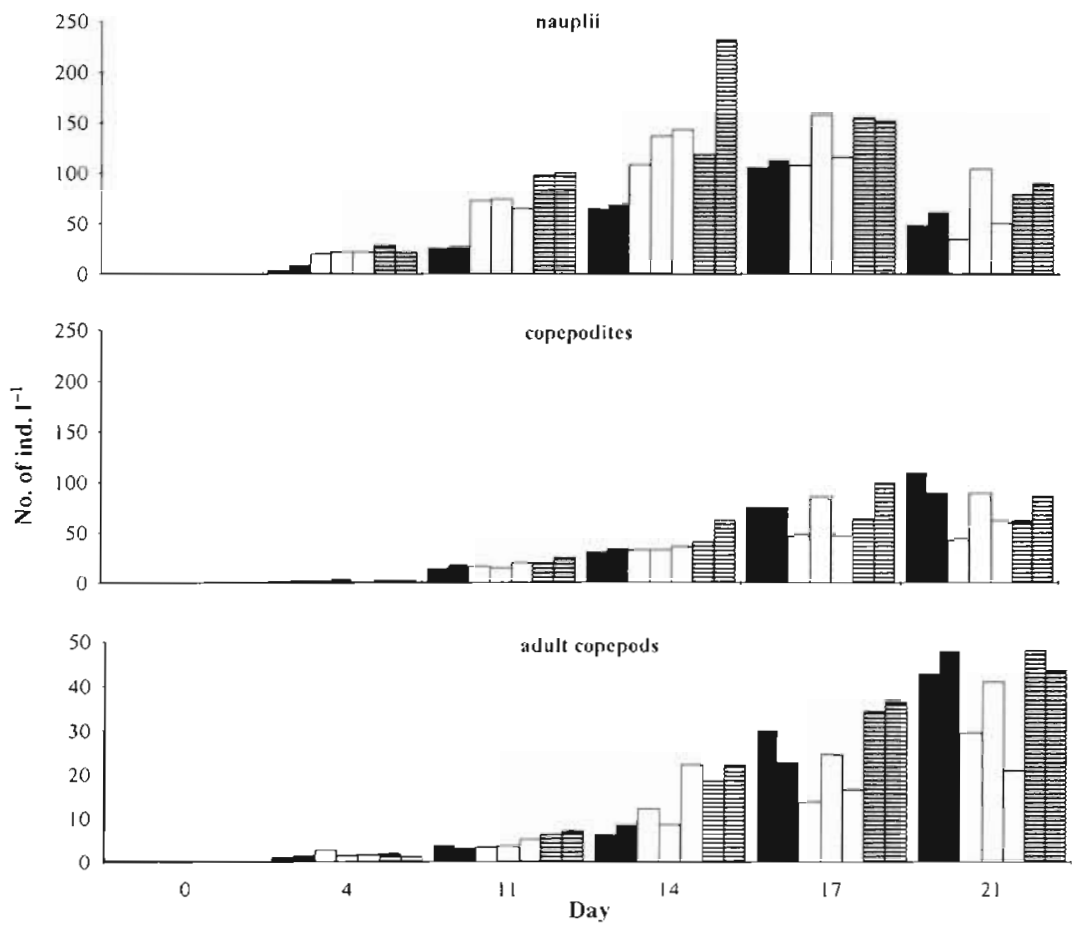

$\square$ ICd+nuts $\square$ 2Cd+nuts $\square$ icontr $\square$ scontr

$\square$ Tcontr 目5+mutr 目6-nuts
Fig. 4. Zooplankton development for the 7 mesocosms in Expt I. Note difference in scale of $y$-axes dance increase was highest up to Day 14. The species composition was: Acartia clausi (45\%), Temora longicornis (25\%), Centropages hamatus (25\%) and P. elongatus $(5 \%)$. The control mesocosms with low nutrient addition exhibited an intermediate zooplankton development, with a species composition of: A. clausi (40\%), $T$. longicornis $(30 \%), C$. hamatus $(20 \%)$, Podon sp. $(5 \%)$ and $P$. elongatus $(5 \%)$. In the cadmium-spiked mesocosms, zooplankton development was retarded and the maximum number of nauplii and copepodites was reached at a later date (Day 17). The species composition was: A. clausi $(30 \%), T$. longicornis $(30 \%)$, C. hamatus (5\%), Podon sp. (30\%) and Pseudocalanus elongatus $(5 \%)$. The cadmium concentration appeared to decrease from about $0.45 \mu \mathrm{M}$ to about $0.10 \mu \mathrm{M}$ at the end of the experiment, which may have been the reason for the observed minor effect of cadmium upon zooplankton.

\section{Expt II (March-April 1992)}

The results of nutrient additions in Expt II were quite similar to those in Expt I. The nitrate concentration (initially $80 \mu \mathrm{M}$ ) became limited (approximately $5 \mu \mathrm{M}$ ) after Day 10 in all mesocosms and stayed low during the rest of the experiment. Phosphate concentrations, initially $3 \mu \mathrm{M}$ for the systems without nutrient dosing and $13 \mu \mathrm{M}$ for the systems that were nutrient dosed, did not become limiting in any of the mesocosms (1 $\mu \mathrm{M}$ and $10 \mu \mathrm{M}$ respectively).
Fig. 5 shows the results of the chl a concentrations, together with [DMS $]_{\text {water }}$ measurements. There was a distinct cycle of 2 phytoplankton blooms like that seen in Expt I. It is clear that the development of phytoplankton in all systems (expressed as chl a) was very similar, notwithstanding treatment.

The first chl a peak, around Day 8, was mainly caused by the diatoms Skeletonema costatum $\left(36 \times 10^{6}\right.$ $\left.\mathrm{l}^{-1}\right)$ and Thalasiosira nordenskioldii $\left(11 \times 10^{6} \mathrm{1}^{-1}\right)$. The second peak, which was less pronounced (Days 20 to $30)$, consisted mainly of Phaeocystis pouchetii $\left(32 \times 10^{6}\right.$ $\left.1^{-1}\right)$.

[DMS $]_{\text {water }}$ initially increased slowly during the first phytoplankton bloom, but a few days after the collapse of the diatom peak [DMS] water increased dramatically in most systems. The collapse of the DMS peak also occurred very quickly, e.g. in mesocosms 2 and 3 the concentration decreased from about $480 \mathrm{nM}$ to about $50 \mathrm{nM}$ in only $1 \mathrm{~d}$. In the other systems this decrease was not as clear, but a decrease of about $300 \mathrm{nM}$ to detection limit values in $3 \mathrm{~d}$ (mesocosms 1 and 6) and a decrease from about $100 \mathrm{nM}$ to detection limit in $2 \mathrm{~d}$ (mesocosms 4 and 5) are also impressive. Here also not all systems showed the same high DMS concentrations. Mesocosms 4 and 5, and to a lesser extent Mesocosm 6 , resulted in lower [DMS] water peaks. Duplicate systems did not always provide similar results for [DMS $]_{\text {water }}$ despite the reasonably good agreement in chl a concentrations, especially during the first blooms. To investigate diurnal variation, on Day 13, [DMS $]_{\text {water }}$ of mesocosm 3 was followed every 2 h over a 24 h period. 
1 fittered

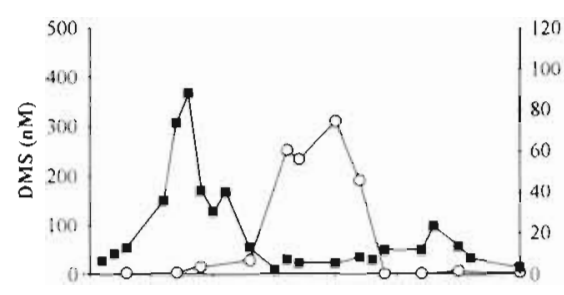

3 control

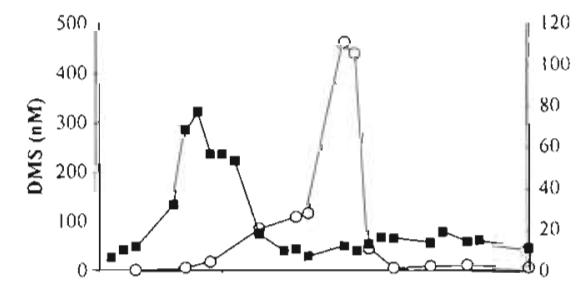

$5+\mathrm{PO}_{4}$

Fig. 5. Development of DMS concentrations in water for the 6 mesocosms in Expt II (Mar-Apr 1992), plotted together with chl a concentrations. Mesocosms 1 and 2: water filtered; mesocosms 3 and 4: controls; mesocosms 5 and $6: 10 \mu \mathrm{M}$ phosphate added

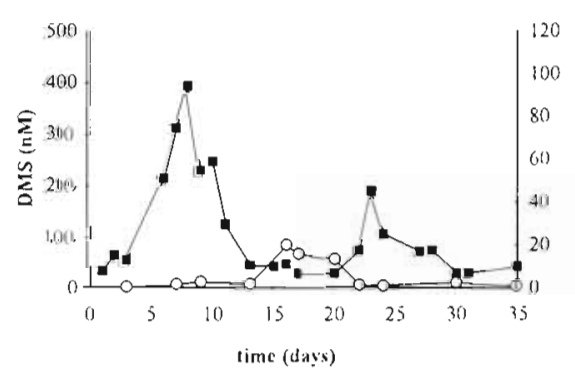

2 filtered
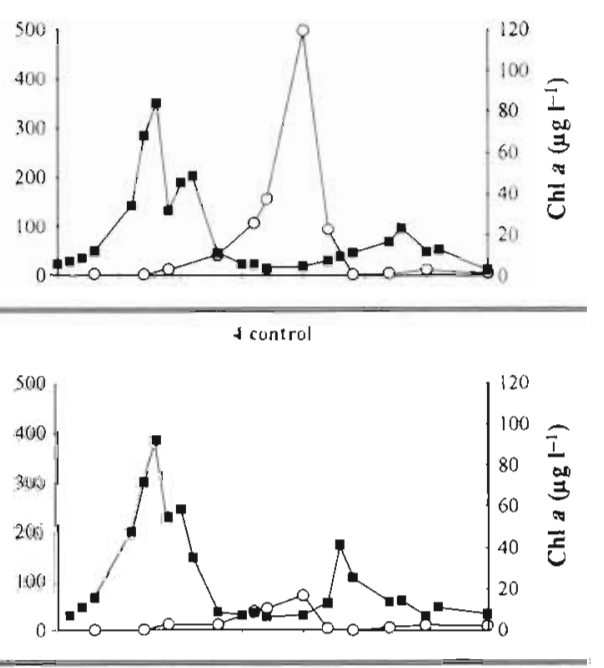

$6+\mathrm{PO}_{4}$

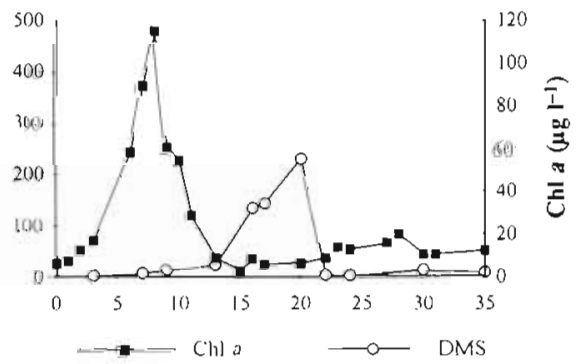

It was found that there may have been a slight diurnal effect as [DMS] water decreased from $80 \mathrm{nM}$ during daytime to about $65 \mathrm{nM}$ at night. [DMS] water outside the mesocosms was about $20 \mathrm{nM}$. In a separate laboratory experiment, the importance of DMS diffusion through the mesocosm material was tested. In $3 \mathrm{wk}$ only a few percent of the DMS dosed in a model plastic bag of mesocosm material appeared in the surrounding water.
Zooplankton development in all 6 mesocosms is shown in Fig. 6 (total number of nauplii, copepodites and adults). There was a large difference between the $55 \mu \mathrm{m}$ filtered and the untreated mesocosms, but not between duplicate mesocosms. Both control mesocosms and the mesocosms with phosphate addition showed an increase in zooplankton numbers towards the end of the experiment. In all non-filtered systems, zooplankton consisted mainly of the species Temora
Fig. 6. Zooplankton (copepods) development for the 6 mesocosms in Expt II. Mesocosms 1 and 2: water filtered; mesocosms 3 and 4: controls; mesocosms 5 and 6: $10 \mu \mathrm{M}$ phosphate added

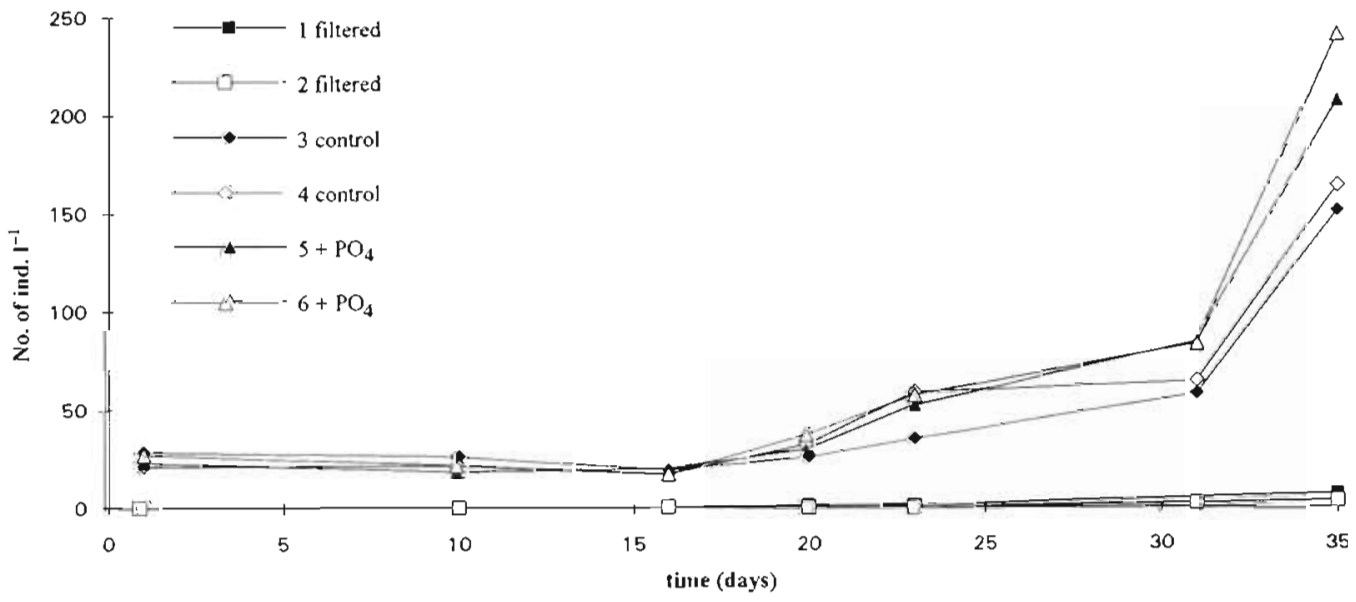


longicornis $(70 \%)$. Other species were: Acartia clausii $(11 \%)$, Centropages hamatus $(11 \%)$ and Pseudocalanus elongatus ( $2 \%)$.

The MPN counts of DMS oxidizing bacteria revealed

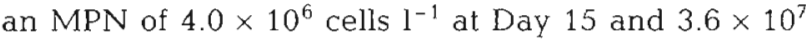
cells $\mathrm{l}^{-1}$ at the end of Expt II (P. Quist pers. comm.).

\section{DISCUSSION}

The results presented above are typical for this kind of experiment (Kuiper 1982). There is a succession of 2 phytoplankton blooms, a diatom bloom followed by a bloom dominated by Phaeocystis sp. It appears that the diatoms in Expt I had already started growing before any nutrients were added. Since the algae were enclosed in a less turbulent system than the Oosterschelde basin and the algae were exposed to a different light situation in the mesocosms to that in the field, these boundary conditions may have stimulated the phytoplankton bloom. This is commonly observed in enclosures (Gieskes \& Kraay 1982).

It is clear from our experiments that a direct correlation does not exist between the concentration of chl a and $[D M S]_{\text {water }}$. In both experiments, DMS release into the water did not occur during the first (diatom) phytoplankton bloom, but started immediately after the onset of its decline. [DMS] water also started to increase after the second bloom (Phaeocystis sp.) in Expt I, while no second bloom was observed during Expt II. The sequence of the production of DMS following a phytoplankton bloom strongly suggests that the release of DMS into the water column is caused by senescence rather than by metabolic excretion. This is in accordance with the results of Nguyen et al. (1988) and Stefels \& van Boekel (1993), who showed that maximum production of DMS occurred after the phytoplankton bloom started to collapse. Leck et al. (1990) also observed this phenomenon after the first chl a peak of a spring bloom in the Baltic Sea, while Matrai \& Keller (1993) reported a maximum release of DMS during the senescence phase of a large Emiliania huxleyi bloom in the Gulf of Maine. In both our experiments, the increase and decrease of [DMS $]_{\text {water }}$ occurred in only 1 or $2 \mathrm{~d}$, which is in accordance with the findings of Leck et al. (1990) in the Baltic Sea who calculated that the turnover time for DMS in the water column was in the order of $2 \mathrm{~d}$. During Expt I, the ratio between maximum [DMS $]_{\text {water }}$ detected in the water and the maximum chl a concentra-

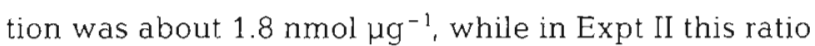
was about $4.4 \mathrm{nmol} \mathrm{\mu g}^{-1}$. According to Keller et al. (1989) Asterionella sp. and Chaetoceros sp., which were the main diatoms in Expt I, contain less DMSP than Skeletonema sp., which was dominant during the first bloom in Expt II
In Expt I the addition of nutrients (see Table 1, Fig. $2 b, c)$ resulted in a larger second phytoplankton bloom. The nitrate becomes limiting after Day 9 (phosphate is levelling out), which coincides with the maximum of DMS release. The start of DMS production is definitely earlier. The idea that DMSP replaces glycine-betaine as an osmoprotectant under nitrogenlimited conditions and will thus be enhanced under these circumstances (Gröne \& Kirst 1992) is not supported by these findings. In Expt II the first phytoplankton (diatom) bloom probably collapses due to a silicate limitation. Although the nitrogen limitation takes place well before the development of the DMS peaks and at the very end of the first bloom, it does not seem realistic to assume that the $\mathrm{N}$-limiting conditions at this late stage of plankton development have induced DMSP (thus DMS) production. There may be a decreased production of DMS in the mesocosms with phosphate addition. However, as there is a large variation between the 2 control mesocosms we prefer not to draw any hasty conclusions on this subject.

In Expt II, $55 \mu \mathrm{m}$ filtering effectively removed copepods at the beginning, and a large difference in zooplankton numbers between $55 \mu \mathrm{m}$ filtered vs nonfiltered mesocosms was observed. The presence of copepods appeared to have little effect on the phytoplankton development. Removal of zooplankton by $55 \mu \mathrm{m}$ filtration did not result in an increased chl a content. Obviously the effect of zooplankton grazing is compensated by stimulated phytoplankton growth. Although there seems to be a coincidence of DMS production and increase in zooplankton numbers, a detailed study of the results indicates that the zooplankton increases almost at or even after the decrease of the DMS peak. The influence of added $\mathrm{CdCl}_{2}$ in Expt I was not as large as expected (Kuiper 1981), but cadmium concentrations decreased to a probably nontoxic concentration early in the experiment. There was a shift in copepod species from Pseudocalanus hamatus in the mesocosms that were unspiked to Podon sp. in the systems with $\mathrm{CdCl}_{2}$ addition, but total copepod numbers did not change noticeably. We did not sample the microzooplankton fraction, as it is very difficult to do quantitatively. In both experiments, the major increase in zooplankton started after the major chl a peak and the maximum release of DMS. This is in contrast to other observations (Belviso et al. 1990, 1993, Leck et al. 1990). However, we have to take into account that the phytoplankton bloom is compressed in time from 3 mo to 1 mo in mesocosms and it may be possible that this resulted in a non-matching of life stages between algae and copepods, thus obscuring a possible grazing effect. According to Hansen \& van Boekel (1991), the copepod Temora longicornis switched from phytoplankton to ciliates as a food 
source during a Phaeocystis sp. bloom in the Marsdiep tidal inlet in 1990. This is an indication that the effect of zooplankton grazing on the release of DMS into the water column may be correlated with certain algal species, e.g. diatoms vs flagellates. Belviso et al. (1990) showed that microzooplankton may be of great importance in releasing DMS in the water column. Wolfe et al. (1994) showed that the hetereotrophic dinoflagellate Oxyrrhis marina may be an important sink for DMSP in marine waters.

There was a considerable difference in [DMS| water between duplicate systems in both experiments. Theoretically there may be several reasons for this discrepancy: sampling and/or analytical errors; differences in phytoplankton species distribution (despite reasonable chl a similarity); differences in zooplankton grazing pressure; photochemical conversion of DMS iffusion of DMS through the mesocosm wall; output to the atmosphere and/or a difference in bacterial consumption of DMS.

In Expt I the sampling frequency may have been the reason for the observed non-comparability of the different systems. Due to the interval between 2 sampling events ( 3 to $4 \mathrm{~d}$ ) the highest DMS concentrations may have been missed. For this reason the sampling intervals in Expt II were decreased to 1 to $2 \mathrm{~d}$. Considering the width of the peaks, we may assume that no peak was missed in these observations although the maximum [DMS] may have been higher than we observed. Nevertheless, relatively large differences were observed here as well.

Analytical errors could have caused these discrepancies. Duplicate analyses revealed that the reproducibility was good, however. The CVs of about 5 to $17 \%$, depending on [DMS $]_{\text {water, }}$ were much smaller than the differences in $[\mathrm{DMS}]_{\text {water }}$ in these experiments.

Differences in phytoplankton species distribution could not have caused the discrepancies between duplicates, as no major taxonomic differences were found.

As to differences in zooplankton grazing pressure, during Expt I, only a shift in zooplankton species composition, but no differences in total zooplankton numbers, was observed. Furthermore, maximum numbers were reached well after the phytoplankton bloom and the maximum release of DMS. During Expt II, a large difference in zooplankton numbers between $55 \mu \mathrm{m}$ mesh filtered mesocosms and untreated mesocosms was observed, but not between duplicate mesocosms, which makes it unlikely that the copepod zooplankton was responsible for the discrepancy in [DMS $]_{\text {water }}$ between similarly treated systems. Microzooplankton may have had an influence here, but as previously stated, this still remains unclear in this experiment.
Photochemical conversion seems unimportant as the chemical half-life of DMS in water is in the order of months (A. Baart pers comm.). Diffusion through the plastic enclosure material could have played a role as $[D M S]_{\text {water }}$ outside the bags was very low and, thus, a gradient existed. However, the importance of this diffusion was measured in a separate laboratory experiment and proved to be very low.

Fluxes to the atmosphere could also play a role in the removal of DMS from the water column. However, only a part of the DMS disappearing from the water column can be explained by a flux to the atmosphere, as was reported previously (Kwint et al. 1992). All of these last 3 factors are physico-chemical processes, which may have played a role in the removal of DMS in our Expts I and II. It must be emphasized, however, that differences were expected to be low and should at least have been within the same order of magnitude for all mesocosm systems in each experiment. This makes it highly unlikely that these physico-chemical factors were the basis for the differences found.

The variables and processes measured and discussed above do not give an adequate explanation for the large discrepancy between the control systems of the experiments. Changes in [DMS $]_{\text {water }}$ occur rapidly and another (dominant) factor could be responsible for that process. Bacterial consumption may explain this phenomenon. If DMS is rapidly consumed by bacteria, no increase of DMS in the water will be detected. Kiene \& Bates (1990) and Kiene (1990, 1992) suggested that bacterial production of DMS from dissolved DMSP and consumption of DMS and DMSP could be the most important production and consumption factors for DMS in seawater; this was not supported by experimental proof however. In our Expt II, DMS-utilizing bacteria were counted by a selective MPN method. As the bacterial analyses were carried out for only a limited number of samples, only a preliminary estimation of the potential DMS consumption by these bacteria could be obtained. It shows that bacterial consumption of DMS in the mesocosms (1300 l)

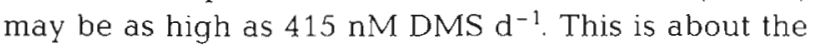
same amount as the entire standing stock of DMS at the maximum values (P. Quist pers. comm.).

Since all other possible interferences failed to provide a reason for the discrepancy between similar mesocosms, bacterial consumption could indeed be the most important factor in removing DMS from the water. Since bacteria have a high reproduction rate, small initial differences in numbers and/or substrate may rapidly lead to significant differences in the resulting effects. Also small shifts in time for these microbial processes between mesocosms may explain the large differences in [DMS $]_{\text {water }}$ between duplicates. When DMS is as rapidly consumed as it is produced, 
then obviously no increase in the water will be detected. Proof still needs to be provided, however.

\section{CONCLUSIONS}

The results of these experiments show that the release of DMS appears to be highly correlated with phytoplankton senescence. [DMS] water can be highly variable in time, while large differences were observed under apparently identical conditions. Maximum release of DMS into the water column occurs in a matter of days rather than weeks. In $1 \mathrm{~d}$ the [DMS $]_{\text {water }}$ can change by an order of magnitude.

Mesocosms are useful in understanding the mechanisms controlling the release of DMS into the water column. They form an essential intermediate stage between laboratory experiments and the field. However, care must be taken when extrapolating these results directly to the natural situation. The high variability of $[D M S]_{\text {water }}$ in the mesocosms suggests that under natural conditions also, the period of maximum emission of DMS could be relatively short. This will have implications for surveys of natural waters, e.g. along a transect not only different plankton species may be present, but also different phases of a bloom development may result in highly variable DMS measurements, which are not easy to interpret. Large variations of $[\mathrm{DMS}]_{\text {water, }}$ even between days, means that relatively short sampling intervals or synoptic sampling are a prerequisite before proper isolines can be drawn.

Acknowledgements. The authors thank the following people: Gerrit Hoornsman, Marijke van der Meer, Ad van Mullem and Henk Verhagen for their technical assistance. We also thank the captains of the RV 'Nauplius II' for all the safe passages and Peter Quist of the Department of Microbiology of the University of Groningen for his co-operation in providing estimates for bacterial consumption. Co-operation and stimulating discussion with Robbert Jak and Arthur Baart is gratefully acknowledged. This project could not have been carried out without the hospitality of the Department of Analytical Chemistry TNO. Without the expertise of Finn 'Bill' Lindqvist (who unfortunately died shortly after his retirement) in the analysis of DMS and related compounds, none of this would have been possible to achieve. The project was supported by the Dutch government (Ministry of VROM) under contract number NOLK/026/90.

\section{LITERATURE CITED}

Andreae MO (1990) Ocean-atmosphere interactions in the global biogeochemical sulphur cycle. Mar Chem 30:1-29 Belviso S, Buat-menard P, Nguyen BC, Claustre H, Neveux J (1993) Size distribution of dimethylsulfoniopropionate (DMSP) in areas of the tropical northeastern Atlantic Ocean and the Mediterranean Sea. Mar Chem 44:55-71
Belviso S, Kim SK, Rassoulzadegan F, Krajka B, Nguyen BC, Mihalopoulos N, Buat-menard P (1990) Production of dimethylsulfonium propionate (DMSP) and dimethylsulfide (DMS) by a microbial food web. Limnol Oceanogr 35:1810-1821

Bürgermeister S, Georgii HW (1991) Distribution of methanesulfonate, NSS sulfate and dimethylsulfide over the Atlantic and the North Sea. Atmos Environ 25A:587-595

Charlson RJ, Lovelock JE, Andreae MO, Warren SG (1987) Oceanic phytoplankton, atmospheric sulphur, cloud albedo and climate. Nature 326:655-661

Cooper WJ, Matrai PA (1989) Distribution of dimethyl sulfide in the oceans. In: Saltzman ES, Cooper WJ (eds) ACS Symposium series 393. Biogenic sulfur in the environment American Chemical Society, Washington, DC, p 140-151

Dacey JWH. Wakeham SG (1986) Oceanic dimethylsulfide: production during zooplankton grazing on phytoplankton. Science 233:1314-1316

de Man JC (1975) The probability of most probable numbers. Eur J appl Microbiol 1:67-78

Gibson JAE, Garrick RC, Burton HR, McTaggart AR (1990) Dimethylsulfide and the alga Phaeocystis pouchetii in Antarctic coastal waters. Mar Biol 104:339-346

Gieskes WWC, Kraay GW (1982) Effect of enclosure in large plastic bags on diurnal change in oxygen concentration in tropical ocean water. Mar Biol 70:99-104

Gröne T, Kirst GO (1992) The effect of nitrogen deficiency, methionine and inhibitors of methionine metabolism on the DMSP contents of Tetraselmis subcordiformis (Stein). Mar Biol 112:497-503

Hansen FC, van Boekel WHM (1991) Grazing pressure of the calanoid copepod Temora longicornis on a Phaeocystis dominated spring bloom in a Dutch tidal inlet. Mar Ecol Prog Ser 78:123-129

Keller MD, Bellows WK, Guillard RRL (1989) Dimethylsulfide production in marine phytoplankton. In: Saltzman ES, Cooper WJ (eds) ACS Symposium series 393. Biogenic sulfur in the environment. American Chemical Society, Washington, DC, p 167-182

Kiene RP (1990) Dimethylsulfide production from dimethylsulfoniopropionate in coastal seawater samples and bacterial cultures. Appl environ Microbiol 56:3292-3297

Kiene RP (1992) Dynamics of dimethyl sulfide and dimethylsulfoniopropionate in oceanic water samples. Mar Chem $37: 29-52$

Kiene RP, Bates TS (1990) Biological removal of dimethyl sulphide from sea water. Nature 345:702-705

Kiene RP, Service SK (1991) Decomposition of dissolved DMSP and DMS in estuarine waters: dependence on temperature and substrate concentration. Mar Ecol Prog Ser 76:1-11

Kirst GO, Wanzek M, Haase R, Rapsomanikis S, Demora S Schebeske G, Andreae MO (1992) Ecophysiology of ice algae (Antarctica): dimethylsulfoniopropionate content and release of dimethylsulfide during ice melt. In: Restelli G, Angeletti G (eds) Dimethylsulphide: oceans, atmosphere and climate. Int Symp Proc Belgirate. Kluwer Academic Publishing, Dordrecht, p 23-36

Kuiper $\mathbf{J}$ (1981) Fate and effects of cadmium in marine plankton communities in experimental enclosures. Mar Ecol Prog Ser 6:161-174

Kuiper J (1982) The use of enclosed plankton communities in aquatic ecotoxicology. Fate and effects of mercury, cadmium and selected aromatic organics in a marine model ecosystem. PhD thesis, Univ of Wageningen, p 12-20

Kwint RLJ, Kramer KJM, Baart AC, Verhagen HLM (1992) The production of DMS by a plankton community: a meso- 
cosm experiment. In: Restelli G, Angeletti G (eds) Dimethylsulphide: oceans, atmosphere and climate. Int Symp Proc Belgirate. Kluwer Academic Publishing, Dordrecht, p 53-62

Leck C, Larsson U, Bagander LA, Johansson S, Hajdu S (1990) Dimethyl sulfide in the Baltic Sea: annual variability in relation to biological activity. J. geophys. Res. 95/C3: 3353-3363

Leck C, Rodhe H (1991) Emissions of marine biogenic sulfur to the atmosphere of northern Europe. J Atmos Chem $12: 63-86$

Lindqvist $F$ (1989) Sulfur-specific detection in air by photoionization in a multiple detector gas chromatographic system. J High Res Chrom 12:628-631

Liss PS, Malin G, Turner SM (1992) Production of DMS by marine phytoplankton. In: Restelli $G$, Angeletti $G$ (eds) Dimethylsulphide: oceans, atmosphere and climate. Int Symp Proc Belgirate. Kluwer Academic Publishing, Dordrecht, $\mathrm{p} 1-14$

Matrai PA, Keller MD (1993) Dimethylsulfide in a large-scale coccolithophore bloom in the Gulf of Maine. Cont Shelf Res 13(8/9):831-843

Nguyen BC, Belviso S, Mihalopoulos N, Gostan J, Nival P (1988) Dimethyl sulfide production during natural phytoplanktonic blooms. Mar Chem 24:133-142

Parsons RT, Maita Y, Lalli CM (1984) A manual of chemical and biological methods for seawater analysis. Pergamon Press, Oxford, p 3-111

This article was submitted to the editor
Reid PC, Lancelot C, Gieskes WWC, Hagmeier E, Weichart G (1990) Phytoplankton of the North Sea and its dynamics: a review. Neth J Sea Res 26:295-331

Stefels J, van Boekel WHM (1993) Production of DMS from dissolved DMSP in axenic cultures of the marine phytoplankton species Phaeocystis sp. Mar Ecol Prog Ser 97 : $11-18$

Turner SM, Malin G, Liss PS (1989) Dimethyl sulfide and (dimethylsulfonio)propionate in European coastal and shelf waters. In: Saltzman ES, Cooper WJ (eds)ACS Symposium series 393. Biogenic sulfur in the environment. American Chemical Society, Washington, DC, p 183-200

Turner SM, Malin G, Liss PS, Harbour DS, Holligan PM (1988) The seasonal variation of dimethyl sulfide and dimethylsulfoniopropionate concentrations in nearshore waters Limnol Oceanogr 33:364-375

Vairavamurthy A, Andreae MO, Iverson RL (1985) Biosynthesis of dimethylsulfide and dimethylpropiothetin by Hymenomonas cartarae in relation to sulfur source and salinity variations. Limnol Oceanogr 30:59-70

Wakeham SG, Dacey JWH (1989) Biogeochemical cycling of dimethyl sulfide in marine environments. In: Saltzman ES, Cooper WJ (eds) ACS Symposium series 393. Biogenic sulfur in the environment. American Chemical Society, Washington, DC, p 152-166

Wolfe GV, Sherr EB, Sherr BF (1994) Release and consumption of DMSP from Emiliania huxleyi during grazing by Oxyrrhis marina. Mar Ecol Prog Ser 111:111-119

Manuscript first received: July 21, 1994

Revised version accepted: January 20, 1995 